\title{
Legal Analysis of the Establishment of a Special Electoral Court as an Independent State Institution
}

\author{
L. M. Ricard Zeldi Putra ${ }^{\star *}$, La Ode Muhram². \\ ${ }^{1}$ Faculty of Law, Universitas Muhammadiyah Buton, Indonesia \\ 2Faculty of Law, Universitas Sulawesi Tenggara, Indonesia \\ *Correspondence: ricardzeldiputra@gmail.com
}

\section{ARTICLE HISTORY \\ Received: 15.11 .2021 \\ Accepted: 21.12.2021 \\ Published: 27.12.2021 \\ ARTICLE LICENCE \\ Copyright @ 2021 The \\ Author(s): This is an \\ open-access article \\ distributed under the \\ terms of the Creative \\ Commons Attribution \\ ShareAlike 4.0 \\ International (CC BY-SA \\ 4.0)}

\begin{abstract}
Article 24 of the 1945 Constitution only on structure but not on institutional functions where there are still many institutions/agencies in the government that carry out judicial functions. The regulation has led to the emergence of several independent institutions to carry out judicial functions, one of which is a special election court. The research used is normative research with an approach that focuses on the theoretical approach, the statutory approach, the case approach and is described in a qualitative descriptive form. The special election judiciary as an independent institution that will be formed is again from the law that aspires to, namely an institution that is free from intervention and can carry out judicial functions and disputes over the results of the elections. This special court is under the jurisdiction of the Supreme Court and will take the form of ad hoc. Its authority is to examine and adjudicate disputes over election results.
\end{abstract}

Keywords: Establishment; Special Judicial Institution; Independent

\section{Introduction}

The development of the Indonesian state administration through the amendments to the 1945 Constitution is the entrance to a democratic system, marked by the birth of new state institutions. The institution was born on several legal grounds, meaning that there are state institutions whose authorities and institutions are clearly stated in the Constitution, through Decrees of the People's Consultative Assembly, laws (UU), and there are even institutions whose authority comes from Presidential Decrees (Kepres) and Regulations. President (Perpres). These function called check and balance (Rizki A, Suhartono, \& Salam, 2021)

Indonesian legal rules have not yet established clear regulations on state in stitutions. According to the author, this also has an impact on several names that are matched with state institutions, including: authorities, commissions, councils, committees, committees, agencies, centers, teams and so on. There are no concrete rules that distinguish some of these terms, whether "institution" is a state institution whose authority and name is mentioned directly by the Constitution and "commission" is an institution whose authority is given by law. These institution in law have a different authority. (Imron Rizki, Safrin Salam, 2019)

If reviewed more far, in fact the limitation of article 24 of the 1945 Constitution only rests on the structure but not on the institutional function where there are still many institutions/agencies within the government that carry out judicial functions. The emergence of independent state institutions that carry out judicial functions, for example:

a) The Business Competition Supervisory Commission (KPPU) was established by Law Number 5 of 1999 concerning the Prohibition of Monopolistic Practices and Unfair Business Competition (UU Business Competition), article 36 stipulates the authority of KPPU especially in points e to point $k$ that KPPU has the authority to examine, adjudicate, and decide cases of business competition violations.

b) The Indonesian Broadcasting Commission (KPI) is an independent state institution established under Law Number 32 of 2002 concerning Broadcasting. Although the final product form is not a decision, it is still 
included in the judicial function because KPI is the institution that has the authority to determine whether or not there is a broadcasting violation as well as to impose sanctions on it.

c) The Election Supervisory Body (Bawaslu) is an independent state institution that has the authority to supervise the Implementation of General Elections and Pilkada, in the Election Law, Bawaslu has the authority to examine, hear, and decide disputes between election participants and Election Contestants and Election organizers as a result of the issuance of Provincial KPU Decrees and Regency/City KPU.

With variousFrom the description above, in fact, so far there are still many independent institutions/bodies that carry out judicial functions that are outside the Supreme Court, so the existence of the Special Elections Judiciary Agency as an independent institution does not have to be under the auspices and become a unit in the Courtunder the Supreme Court because in the end the structure and function of the Judicial Body Special elections will be regulated by separate provisions as well as in the Pilkada Law even though it is ad hoc, including the idea of being taken over by Bawaslu to be irrelevantbecause in cases of dispute over election results, Bawaslu and Regency/Municipal Bawaslu are the parties giving information in the trial. Based on the above The author is interested in studying more deeply which will be set forth in the form of an accredited national scientific journal with the title "Legal Analysis of the Establishment of a Special Election Court as an Independent State Institution ".

\section{Methodology}

The research is normative in nature, with an emphasis on the theoretical, statutory, and case approaches, and is documented in a qualitative descriptive format. The normative juridical method is used to analyze, view, and examine a variety of theoretical issues pertaining to legal principles as they relate to research concerns. $P$ This study is a case of legal researchnoratives being applied in an attempt to examine legal materials using the legal standards established by laws and regulations. The procedure for identifying and inventorying legal resources comprises main legal materials, such as statutory rules, secondary legal materials, such as legal literature and scientific works, and tertiary legal materials, such as law dictionaries. Qualitative analysis is next performed on the legal materials that have been gathered, inventoried, and identified. Fork collects reliable and complete data in this study by completing a literature review and reading, referencing, documenting, and comprehending manyliteratures connected to the topics examined.

\section{Result and Discussion}

One of the characteristics of these institutions, namely the matter of independence, can simply be interpreted that an institution cannot be intervened by other institutions. Jimly Asshiddiqie called the institution an Independent State Institution (LNI). (Asshiddiqie, 2014) or Independent regulatory agencies (IRAs). Independent State Institutions are formed at the will of the state for those who want a new state institution with membership originating from non-state elements, authorized by the state, and financed by the state withouthaving to become state employees.(Alamsyah \& Nurul Huda, 2013). The formation of the LNI can be said to be only reactionary in nature, so it does not have a clear position and dignity in the constitutional system (Tauda, 2011). Congruent with that, Zainal Arifin Mochtar said that the formation of the LNI in Indonesia was sometimes only for reasons of regime imagery, and was formed in a hasty process.(Ramadani, 2020).

LNI problems are not only limited to the problems mentioned above, but also regardingthe independence of the LNI itself. In the concept of Independent Regulatory Agencies, Thacher states that there are several parameters for a state institution to be categorized as an independent state institution, namely:(Thatcher, 2002):

a) Party Politicization of appoinments, namely the extent to which there is politicization in the determination of the leadership of IRAs;

b) Departures (dismissal and resignation), namely the termination of IRAs members before the end of their term of office;

c) The Tenure of IRA members, the longer the term of office, the greater the independence of elected officials;

d) The financial and Staffing resources of IRA, namely independence in terms of finance and resource management; 
e) The use of power to overturn the decisions of IRAs by elected politicians, which is interpreted as the use of power to annul decisions/policies issued by IRAs.

William F. Funk and Robert $\mathrm{H}$. Seamon added that independent state institutions practically carry out government functions by combining legislative, executive and judicial powers or powers that are quasi. Institutions belonging to IRAs also have self-regulatory or rule-making characteristics, namely a kind of autonomy that is given to make their own institutional rules independently.(Ramadani, 2020). according to Peter A Gerrangelos (Gerangelos, 2011) that: In relation to the separation of judicial power in particular, it was 'quite clear from an early date that the judicial power of the Commonwealth was regarded as in a special category'. The purpose to be achieved here, ultimately, was the sure protection of the rule of law. (With respect to the separation of judicial powers in particular, it is quite clear from an early date that the judicial power of developed countries is considered a special category. The goal to be achieved in the end, is the protection of the law). The creation of a legal supremacy in the Indonesian constitutional system through the recognition of legal protection of human rights aimed at law order is a dream. Public The state and the ideals of a democratic rule of law.

The Special Electoral Judiciary Agency which will be formed as part of the aspired law (ius constituendum) is an independent institution because it must be free from the intervention of other powers. This body will carry out the judicial function of examining and deciding disputes over the results of the Regional Head Elections. Therefore, the independence of the Special Electoral Court can be described as follows, in accordance with the parameters of the IndependentRegulatory Agencies above, namely:

Party Politicization of appoinmentsThere are 5 (five) judges at the Special Electoral Court, consisting of 2 (two) constitutional judges and 3 (three) ad hoc judges. Ad hoc judges are appointed and dismissed by the President as the Head of State at the suggestion of the Chief Justice of the Constitutional Court. (Salam \& Suhartono, 2020) The ad hoc Special Electoral Judiciary Agency was formed at the proposal of the House of Representatives of the Republic of Indonesia by law.

1. Departures(dismissal and resign). Ad Hoc Judges are honorably dismissed from their positions, because: a. die; b. own request; c. continuous physical or mental illness for 6 (six) months based on a doctor's certificate made by an authorized doctor; $d$. not proficient in carrying out their duties; or e. have finished their term of office. The honorable dismissal as referred to above is determined by the Presidentat the suggestion of the Chief Justice of the Constitutional Court.

Ad Hoc judges are dishonorably dismissed from their positions, on the grounds that: a. sentenced to imprisonment based on a court decision that has permanent legal force for committing a crime punishable by imprisonment of 5 (five) years or more; b. for 3 (three) times in a row neglecting his obligations in carrying out his work duties without a valid reason; $c$. violating the oath or promise of office; $d$. commit a disgraceful act; or e. double job.

2. The Tenure of IRA members. Ad hoc judges are appointed for 5 (five) years and may be reappointed for 1 (one) term of office.

3. The financial and Staffing resources of IRA. The budget for the Special Electoral Court is charged to the State Revenue and Expenditure Budget.

4. The use of power to overturn the decisions of IRAs by elected politicians. The Special Electoral Court has the authority to stipulate a code of ethics and/or code of conduct for judges to gether with the Constitutional Court.

5. Sanctioning Authorities/Quasi judicial power. Conducting verification, clarification, and investigation of reports of alleged violations of the Code of Ethics and/or Code of Conduct of Judges in a closed manner; In the event that the alleged violation of the Code of Ethics and/or Code of Conduct of Judges is proven proven, the Special Electoral Judiciary Agency proposes to impose sanctions on Judges who are suspected of violating the Constitutional Court.

6. Self-regulatoryor rule making. The Special Electoral Judiciary Body can make its own institutional rules independently.

Based on this conception, it can be seen that the Special Electoral Court is an institution with sufficient independence, because in determining judges itis not the full authority of the Special Courts. This does not mean 
that it will have a bad impact, because the process is a form of embodiment of the principle of checks and balances, in which the principle of checks and balances is a logical consequence of the democratic system chosen and practiced by Indonesia. This principle aims that all state institutions can control and balance each other so that no institution is superior or higher than other state institutions.

Furthermore, several literatures have provided a little description of the Special Judicial Body, in particular to answer the question of which environment the Special Judicial Body will be formed in, will it be under the Supreme Court, or will it be returned to the Constitutional Court, or will it become a quasi-judicial institution that only carry out judicial functions and are not in the branch of judicial power butare part of other powers. Supriyadi and Aminuddin Kasim in their scientific work entitled "Design of the Special Election Court after the Decision of the Constitutional Court Number 97/PUU-XI/2013" conveyed a scientific narrative about the Special Judicial Body.

In the a quo scientific work, in accordance with the decision of the Constitutional Court Number 97/PUU XI/2013 and the Law on the Election of Regional Heads, a Special Judicial Body will be established within the judicial environment of the Supreme Court. In other words, there will be an additional judicial environment under the Supreme Court: General Courts, Religious Courts, Military Courts, and State Administrative Courts (TUN Courts), as well as additional Special Courts.

Another basic argument used to build the narrative in the scientific work is Article 1 point 8 of Law Number 48 of 2009 concerning Judicial Power, which states "Special Courts are courts that have the authority to examine, hear and decide on certain cases which can only be established in a special case. one of the judicial bodies under the Supreme Court which is regulated by law".If you look at the article, especially in the sentence "[...] a special court is only formed in one of the court bodies under the Supreme Court [...]" and then it is linked to the picture presented by Supriyadi and Amuniddin, it can be said that the Special Judicial Body is the environment The new judicial body under the Supreme Court is not appropriate if it uses the argumentation basis of Article 1 point 8 of the Law on Judicial Power, because the a quo article explicitly states that a special court is formed in one of the courts under the Supreme Court, in this case in the general court environment (special court for corruption, special court for children and so on), the religious court environment, the military court environment and the administrative court environment.

The concept presented above can basically be agreed upon with a few notes: first, in accordance with several regulations which state that special courts can only be formed in one of the judicial bodies under the Supreme Court, the Special Judicial Body will be formed in one of the four judicial circles in Indonesia. under the Supreme Court. Regarding which judicial environment can be discussed specifically in other scientific works, whether it is in the general court environment and the Special Courts Agency not only resolves disputes over election results but also administers election crimes, or is in the TUN judicial environment. According to the author himself, the Special Judicial Body can also be formed and is under the Constitutional Court, further discussion on this will be presented in the next sub-chapter.

Furthermore, the Special Electoral Court will take the form of ad hoc. There is no specific regulation that describes ad hoc institutions. Mahfud MD (Prawiro, 2018), explain what is meant by ad hoc is that from the beginning it was intended to be temporary until a normal situation occurs. While Asshiddiqie did not explain the meaning of ad hoc, he only said that "[...] there are also institutions that are ad hoc or not permanent. (Asshiddiqie, 2008)" From the narrative, it can be said that ad hoc institutions are temporary or non-permanent state institutions that were formed to handle certain events. John Alder as quoted by Asshiddiqie argues that ad hoc institutions still have constitutional justification reasons, it is said that (Alder, 2005).

"Ad hoc bodies can equally be used as a method of dispersing power or as a method of concentrating power in the hands of central government nominees without the safeguard of parliamentary or democratic accountability. The extent of governmental control can be manipulated according to the particular circumstances." Sir Ivor Jennings (Asshiddiqie, 2008) states that ad hoc institutions in the UK were formed for various one of 5 (five) main reasons, including: "The need to provide cultural or personal services supposedly free from the risk of political interference. The growing need to provide cultural or personalized services thatare ideally free from the risk of political interference, such as the BBC (British Broadcasting Corporation); The desirability of non-political regulation of markets. There is a desire to regulate market dynamics that are completely non-political, such as the 
Milk Marketing Boards; The regulation of independent professions such as medicine and the law. The need to regulate independent professions such as in the field of medical law; The provisions of technical services.

The need to enact regulations regarding technical services, such as the establishment of a commission, the Forestry Commission; The creation of informal judicial machinery for settling disputes. The establishment of various institutions that function as semi-judicial tools to resolve various disputes outside the judiciary as 'alternative dispute resolution' (ADR). Alder then added one reason for the formation of an ad hoc institution, namely, the idea that public ownership of key sectors of the economy is desirable in itself. This means that public ownership in the economic field or certain sectors is considered more appropriate to be organized in a separate organization, as has been developed recently, for example with the idea of a State-Owned Legal Entity (BHMN) (Asshiddiqie, 2008).

In the context of Indonesia, the basis for the formation of ad hoc institutions is usually based on the need to resolve problems quickly with limited time. In addition, the formation of an ad hoc institution occurred because the initial institution that carried out certain tasks and functions was unable to fulfill it optimally or the initial institution was over tasked and functional. (Safrin Salam, 2020) Or cases that are too piled up, so that to solve the problem a temporary ad hoc institution is formed, and when the problem has been resolved, the ad hoc institution can be dissolved. Although in some literature it is said that state institutions are ad hoc in nature for a certain period, in practice due to the large number of them, even though the time has run out, these institutions have not or have not been dissolved. Another problem caused by unclear regulations regarding ad hoc institutions, gave rise to opinions about institutions that were originally known as ad hoc institutions, which are now considered no longer temporary, for example, some experts say that the Corruption Eradication Commission is not an ad hoc institution, as well as the Ombudsman. The pretext that is often used to refute the justification of ad hoc institutions is that the laws and regulations that form the basis for the establishment of the institution (which are considered ad hoc in nature) do not contain provisions which implicitly state that the institution is ad hoc. Therefore, this should also get attention, because there are consequences attached to the justification of ad hoc institutions, in this case the institution can be dissolved at any time.(Salam, 2019)

Furthermore, several ad hoc institutions burden the state financially. This is because the administrators of ad hoc institutions continue to receive salaries from the APBN or APBD because these institutions have not been disbanded, even though the time limit has been reached and problems have been resolved so that certain tasks and functions can be carried out normally by the initial institution (not ad hoc institutions). Again, the issue of unclear regulations governing ad hoc institutions is one of the causes of the birth of this problem. With the existence of regulations that contain provisions on the formation and dissolution of ad hoc institutions, it is hoped that some of the problems mentioned above will be resolved. However, in the case of the establishment of the Special Electoral Court, this assumption must be dismissed

\section{Conclusion}

The Special Elections Judiciary Agency is an independent state institution authorized to resolve regional election disputes which are in an ad hoc (temporary) form. Ad hoc institutions are formed because of the need to provide services without any outside interference, the desire to regulate non-political dynamics, regulate independent professions and as a semi-judicial complementary tool to resolve disputes. Therefore, this special election court institution is needed to resolve problems quickly with limited time.

\section{References}

Alamsyah, B., \& Nurul Huda, U. (2013). Legal Politics of Institutionalization of State Commissions in the Indonesian Constitutional System. Journal of Law and Justice, 2(1), 85. https://doi.org/10.25216/jhp.2.1.2013.85-108

Alder, J. (2005). Constitutional and Administrative Law. London: Palgrave Macmillan.

Asshiddiqie, J. (2008). Relations between State Institutions after the Amendment of the 1945 Constitution. Jakarta: Sekneg RI.

Asshiddiqie, J. (2014). Introduction to Constitutional Law. Jakarta: Rajawali Press.

Gerangelos, P. (2011). The Separation of Powers and Legislative Interference in Judicial Process Constitutional Principles and Limitations (1st ed.). London: Bloomsbury Publishing. 
Imron Rizki, Safrin Salam, A. M. (2019). Menguji Eksistensi Pengadilan Agama Dalam Menyelesaikan Sengketa Ekonomi Syariah. Indonesia Journal of Criminal Law, 1(1), 65-76.

Prawiro, M. (2018). Pengertian Ad Hoc Dalam Pemilu, Hukum, Jaringan, dan Organisasi.

Ramadani, R. (2020). Independent State Institutions in Indonesia in Perspective of the Concept of Independent Regulatory Agencies. Journal of Law lus Quia lustum, 27(1). https://doi.org/10.20885/iustum.vol27.iss1.art9

Rizki A, I., Suhartono, R. M., \& Salam, S. (2021). Implementation of State Administrative Court Decisions: Conception, and Barriers. Musamus Law Review, 3(2), 49-57. https://doi.org/10.35724/mularev.v3i2.3449

Safrin Salam, D. (2020). Perkembangan Filsafat Hukum Kontemporer. Zifatama Jawara. Retrieved from https://books.google.co.id/books?id=Rf7_DwAAQBAJ\&dq=+safrin+salam+filsafat+hukum\&lr=\&hl=id\&sourc e=gbs_navlinks_s

Salam, S. (2019). Rekonstruksi Paradima Filsafat IImu : Studi Kritis Terhadap IImu Hukum Sebagai IImu. Ekspose: Jurnal Penelitian Hukum Dan Pendidikan, 18(2), HIm. 885-896. Retrieved from https://books.google.co.id/books?hl=id\&lr=\&id=Rf7_DwAAQBAJ\&oi=fnd\&pg=PA1\&dq=safrin+salam\&ots=d $y L n J U H x n i \& s i g=r D 9 C 2 n D Y D y i-96 X i K c J f G x f o A h w \& r e d i r \_e s c=y \# v=o n e p a g e \& q=s a f r i n ~ s a l a m \& f=f a l s e$

Salam, S., \& Suhartono, R. M. (2020). The Existence Legal Certainty of the Truth and Reconciliation Commission in Indonesia. Musamus Law Review, 2(2), 76-85. https://doi.org/10.35724/mularev.v2i2.2849

Tauda, G. A. (2011). The position of the Independent State Commission in the Indonesian Constitutional Structure. Journal of Legal Institutions, 6 N, 173(2).

Thatcher, M. (2002). Independentregulatory agencies in Europe. Risk and Regulation Magazine, 9(6), 117. 